\title{
Gender Representation in The English Textbook for Grade Ninth in Indonesia
}

\author{
Wafda 'Aini \\ wafda.aini17179@student.unsika.ac.id
}

Elih Sutisna Yanto

elih.sutisna@fkip.unsika.ac.id

Wahyudin Fitriyana

wahyudin.fitriyana@staff.unsika.ac.id

\section{Universitas Singaperbangsa Karawang}

\begin{abstract}
This study aims to examine how different genders are represented in Indonesia's grade eight English textbooks. The primary goal of this research is to ascertain the various gender representations and how language and images are used in the English textbook "Think Globally Act Locally." The study employs Fairclough's (1989) Critical Discourse Analysis (CDA) frameworks, specifically the description, interpretation, and explanation. Analyses are divided into five categories: Authors' genders, character genders, issues centered on men or women pictures and visibility, and linguistic traits. Additionally, the images have been subjected to a critical image analysis using the Critical Image Analysis program. The investigation's findings reveal that gender prejudice or stereotypes persist in the English textbooks used in Indonesian schools, despite the government's efforts to promote equality and fairness in education through the country's educational policy. Lastly, the study offers some pedagogical implications and recommendations for resolving gender inequality in the educational materials used in English classrooms.
\end{abstract}

Keywords: Gender Difference; English Text Book

\section{INTRODUCTION}

The international community has recognized the importance of education in promoting and achieving gender equality for an extended period of time. Global statements like UNESCO 2003 and the Millennium Development Goals (UNDP 2000), by 2015, the goal is to eradicate gender inequality at all educational levels. Besides the humanistic imperative to promote the general welfare of a larger number of people, efforts justify alleged significant contributions to reducing poverty, economic growth, and equity. As stated in a UNESCO article, Equality between men and women is "a way of combating poverty and ensuring sustainable growth, for females are positive in all areas of social activities such as health, demography, the economy, education for children, and the welfare of the community" (UNESCO 2007, p. 18). 
Textbooks are considered to have a crucial role to play in socializing or transmitting knowledge and values. Different studies (e.g., Baldwin et Baldwin, 1992; Sadker et al., 2009), for example, have noted that the use of textbooks accounts for 70-90\% of schooling time in various parts of the world. Moreover, textbooks are often an official version of reality - the truth, ideas, and 'important' printed knowledge, sanctioned and promoted by the government or society in general. "The textbook sets many basic conditions for education and learning in schools in many countries worldwide, and the textbook defines what should be passed on by the elite and the right culture," stated "Michael Apple (Apple 1986, p. 81).

Textbooks serve as a curriculum tool to assist teachers and students in recognizing and learning about society's values. (Cho and Park 2014; Widodo 2018). This curriculum artifact organizes values that teachers and students may be aware of (Gebregeorgis 2016; Setyono and Widodo 2019; Widodo 2018). For example, textbooks can be a powerful tool for instilling gender-specific values in teachers and students (e.g., gender equality or stereotyping). Textbooks provide a curriculum strategy to help teachers and students learn about the importance of society. (see Lee 2019; Setyono 2018).

Teaching in gender may be influenced by language textbooks that analyze specific gendered roles, identities, and discourses. If language students consider textbooks a credible resource, Bayyurt and Litosseliti (2006) suggest language students update gender values in textbooks. In this relation, textbook designers and English teachers should focus on gender issues and gender discourse in developing educational materials to ensure that students have adequate gender knowledge and awareness. They must do so while considering gendered content presented visually and verbally in language textbooks (Widodo \& Elyas, 2020). As a result, applied linguists have advocated for a critical approach to the design and use of language textbooks to ensure that they are sensitive to gender values.

In addition, the roles of women and men in society must be balanced. This situation is also called equality between men and women. This can be achieved if women and men have the same status and equal opportunity to exercise their human rights and fully exploit their potential to contribute to and benefit from political, economic, social, and cultural development (UNESCO, 2015: 10). Either man or woman has the opportunity to express their ideas and act freely without being bound by their sexual status. The term equality between gender and equity is also used interchangeably. However, gender equity is the opposite meaning. This condition is also called sexism, in which discrimination based on sexual membership can be described in the social context (Wodak, 1997: 7). Bias or sexism occurs when one sex is unfairly treated another. Later, the term gender bias is more frequently used in this study as this is the subject of the study.

In this study, stereotyped sexual roles are more broadly examined in sex-related jobs and sex-based activities. These relate to Jones et al.'s occupational and social roles (1997). Therefore, it is important to study what kind of jobs are targeted at 
females and males to know the ideology about the sexual roles in the textbook. For example, women are contained in jobs as students and nurses, while men are depicted in various positions such as police officers, doctors, farmers, soldiers, and teachers (Ansary and Babaii, 2003). Similarly, each textbook's suggested activities for males and females should be scrutinized. Thus, the broad perspectives on gender social roles can be detailed. For example, Damayanti (2014) discovered that females were depicted as more dependent than males and were also construed as admirers of male-performed actions in one of Indonesia's pictorial textbook studies.

Some studies have been undertaken throughout the years to examine how gender is portrayed in textbooks. Not only did the researchers examine the visual representations such as illustrations and images, but they also looked at the text for signs of gender discrimination or stereotyping and the usage of sexist language. This study examines how gender is portrayed in course materials, reading passages, conversations, exercises, and images in English textbooks. In theory, no thorough research is conducted solely on these parts of the textbook used during the analysis; this current study fills the void. To ascertain how language is used in English textbooks for ninth-grade students in Indonesian secondary schools and the text images conveyed. As an individual's upbringing shapes their vocabulary from an early age, it is necessary to identify the language used in textbooks. Children tend to learn and remember what they learn from books. Thus, familiarity with the language in these textbooks and the messages conveyed via the images can provide insight into how genders are represented to learners.

\section{LITERATURE REVIEW}

\section{Previous Study}

In a departure from previous research, Lee and Mahmoudi-Gahrouei (2020) examined verbal and visual texts in contemporary Iranian EFL textbooks using computational and manual analysis. Additionally, they investigated Iranian teachers' perspectives on gender issues in selected textbooks. The evidence revealed that, despite gender-neutral vocabularies, men were still depicted more prominently in visual representation than females. In a previous study by Lee (2014), two primary English textbooks were examined in Hong Kong. Lee discovered that while women were underrepresented visually and textually, men had more social roles than females.

Dahmardeh and Kim (2020) conducted another discourse study in which they used qualitative content analysis to examine four new local Iranian coursebooks. In both linguistic and visual examples, males outnumbered females. Men were also cast as career performers or agents. Mengistie and Worku (2021) found comparable results after analyzing a grade 8 Ethiopian EFL textbook. Women are underrepresented in visual illustrations, gender-related terminology, and specialized vocations. Male characters were also shown to be more active dialog starters than female characters. 
Ariyanto (2018) investigated gender prejudice in an Indonesian ELT textbook for junior high students.

The results revealed that the ELT textbook showed stereotypical gender differences between men and women. Yang (2016) conducted a visual analysis of two Englishlanguage manuals used in most of Hong Kong's elementary schools. The study's findings indicated that women were more typically depicted with long hair and clothes. Because blue is frequently associated with men and pink with women, only a small number of the male and female characters in the film were clothed in pink or blue. In the illustrations of the analyzed textbooks, Yang (2016) found no evidence of sex stereotyping. Some EFL studies (for example, Ariyanto 2018; Saputra 2019; Setyono 2018), particularly in Indonesian EFL contexts, show that most EFL textbooks used in Indonesian schools have an unequal representation of male and female characters.

Damayanti (2014) also noted that males tended to outnumber females in Indonesian primary school English textbooks. Females were viewed as more reliant than males. Females were more likely to be regarded for their "beautiful" physical appearance than males. Gender roles are unbalanced for men and women (Damayanti 2014).In this regard, women are underrepresented in Indonesian EFL textbooks. The current study will examine how female visibility is represented in English language textbooks from a gender role perspective to substantiate these findings.

\section{Gender Representation}

Since the 14th century, "gender" has been used as a grammar term for substantive classes in specific languages designated as male, female, or neuter. Since the 14th century, "the state of being masculine or feminine" was also used, but not until the 20th century. Sex and sex often refer to biodiversity, but sex refers to cultural or social differences (Calvert, 2014; Keplinger, Kowal \& Mäkiö, 2016; Kowal, Keplinger \& Maekioe, 2016). They are commonly used in different ways (sex, sex, sex).

Previous research showed that gender underrepresentation or overrepresentation was presented in school books. Initially, as Atchison (2017) reported, gender was not well represented in American government books, as gender issues in political science may not be highlighted. A review of 10 textbooks in introductory political science revealed that gendered content is still far from proportional in the textbooks. Sarvarzade and Wotipka's (2017) study investigated the politicization and expression of gender ideologies in Afghanistan in schoolbooks between 1980 and 2010. According to Sarvarzade and Wotipka (2017), Afghanistan's past has influenced how social and work activities and Afghan women and girls are portrayed. This means that the government has adjusted gender standards. 


\section{Representations of Femininity}

For over forty years, feminism has been a well-known social philosophy, and during that time, the changes in women's roles in modern society have been nothing short of phenomenal. Women's media representations, on the other hand, remain worryingly consistent. Is this evidence that women's standing has remained unchanged or that the macho media refuse to acknowledge it has? Women's representation in all media tends to emphasize the following: (a) beauty (within constrained conventions); (b) size/physics (within constrained conventions); (c) sexuality (as stated previously); (d) emotive (as opposed to intellectual) relationships; and (e) intercourse (as opposed to freedom/independence).

Setyono (2018) discovered in English Language Teaching that certain gender discourses demonstrated by female characters and social actors in the researched textbooks contributed to the perpetuation of gender biases and stereotypes through a women's critical perspective. However, his findings showed that some new speeches depicted positive images of women. Some textbooks depicted job opportunities for women in the modern era. Women were also positively portrayed in textbooks that discussed a woman's broader role as a leader in government. Saputra (2019) also noted that women were not fairly represented in EFL textbooks. His content analysis of 1896 characters and 1344 images depicting males and females in EFL textbooks revealed that male characters had a more excellent representation than female counterparts.

\section{Gender Identity and Bias}

The internal perception of gender of an individual, which may or may not coincide with the gender assigned at birth. "Woman," "transman," and "agender" are just a few examples of gender identities. Due to the internal nature of gender identity, it is not always evident to others. Additionally, gender identity and sex are frequently muddled, even though they are distinct concepts. Cultural identification refers to an individual's sense of belonging to a group or culture or to the extent to which that group or culture impacts them.

Gender discrimination can also be indirectly taught through selecting educational instruments. Using texts that eliminate women's contributions, tokenize women's experiences, or gender stereotypes reinforce gender biases in school curricula. (2012) Anderson et al. (Ahn et al.; Holmes et al.) Gender discrimination in school is a harmful problem that only a few people talk about. Due to years of training, the victims were schooled to remain silent and docile and unwilling to talk about their wrongful treatment. "The disproportionate distribution of teacher time, energy, attention, and talent with males who the lion shares have an overwhelming impact on girls over time."

Much research on gender equity in English textbooks has been published in recent years (e.g., gender bias or stereotypes). Lee (2018) examined gender representation 
in four 2011 EFL series textbooks aimed at Japanese high school students. The results showed that the authors were aware of minimizing the gender disparity by using a women's neutral title (i.e., Ms) and gender-inclusive language to address gender people (e.g., police or police officer instead of policeman). Males are often first mentioned in textbooks, however, and gender inequality still exists for women. Lee (2019) conducted another study, using texts derived from three Japanese high school EFL books published in 2017, which examined the efforts of the Japanese government to promote equality between men and women.

\section{METHOD}

\section{Design and Sample}

This research used qualitative descriptive method. This research used English textbook book in grade ninth with the title "Globally Think Locally" (MONEC). This book was written by Siti Wachidah et.al.

\section{Instrument and Procedure}

The instrument of this research is the researcher's opinion about the content of English text book. The textbook for junior high school entitled "Think Globally, Act Locally." was selected for an in-depth review in this study based on the following criteria:

1. The text of a curriculum is mandated and widely used across the country

2. It was the most recent revision of Grade 9 as one of the current products of the Indonesian ELT curriculum (the 2013 curriculum) to include both hard and soft skills (e.g., gender values).

3. The selected textbook contains numerous illustrations or visual texts, including single images, speech bubbles, and images with dialogue that convey various gender values.

4. The textbook was written by Indonesians who are well acquainted with the history of EFL instruction in the country.

5. The textbook was published by the Ministry of National Education in the Indonesian Government's Pusat Kurikulum dan Perbukuan, Balitbang, Kemdikbud.

\section{Data Analysis}

The method was used to analyze this study using a Critical Disk Analysis/CDA part that focuses mainly on the content or textual analysis of sexes in three English textbooks. The researcher has adapted part of the Fairclough model (1989), one of the most widely used approaches to gender representation in EFL/ESL textbooks. For the analysis of text and discourse, Fairclough's three-dimensional framework consists of - (1) the linguistic description of the text's formal characteristics; (2) the interpretation of the link between the discursive process and interaction with the text; The explanation of the links in the intermediary discourse with social and cultural reality. The following explanation is used: schema, frame, and script 
(Fairclough, 1989). In other words, textbooks, as a form of syllabus, incorporate ideological ideals such as gender inequality into language use in ways that teachers may not be aware of.

\section{RESULT AND DISCUSSION}

The study focused on images, language features, and plots to answer the research questions. The text, images, exercises, dialogues, and captions have all been subjected to qualitative analysis, with the results discussed.

\section{Activities In Image}

The images in the textbooks depict various activities, including riding bicycles, setting up a tent, participating in sports, reading, and conversing. The majority of actions shown in the images require physical strength and are therefore considered masculine. Additionally, neutral activities such as sitting at a school desk, resting, preaching, and playing are demonstrated.

\section{Active Participate in Image}

Tablel 1. Active Participate in Image

\begin{tabular}{|ll|l|l|l|}
\hline & & Male & Female & Both \\
\hline $\begin{array}{l}\text { Think Globally } \\
\text { Locally }\end{array}$ & Act & $85 \%$ & $13 \%$ & $2 \%$ \\
\hline
\end{tabular}

The data demonstrate that males dominate females in textbooks when it comes to active participants in imagery. This male dominance suggests that in Indonesian society, girls are still viewed as second-class citizens, not equal to males, and hence are not shown in active roles alongside males.

\section{Characters on the textbook}

Tablel 2. Characters on Textbook

\begin{tabular}{|lr|l|l|l|}
\hline & & Male & Female & Unknown \\
\hline $\begin{array}{l}\text { Think Globally } \\
\text { Locally }\end{array}$ & $55 \%$ & $45 \%$ & \\
\hline
\end{tabular}

The findings indicate that male characters outperform female and neutral feelings. The answer could be that the authors believe that having equal female or neutral characters in every narrative limits their originality and imaginative flexibility regarding storyline and plot considerations. However, the Selection Committee should have in mind that including stories with female protagonists will assist pupils in understanding that girls have equal representation in society, even in a male-dominated culture. Indian civilization is changing, and with it, the role of women in society. Still, these changes are not mentioned in texts, which play a significant role in educating the community. Therefore, to educate young students 
about the positions of the many genders in society, this should begin with an examination of the various teaching materials utilized in classrooms throughout Indonesia

\section{Status In Image}

Men are frequently depicted in Globally Think Locally as having status (as leaders, heroes, councilors, etc. ), whereas women are rarely represented in such embodiments. However, the data imply that girls with status have been underrepresented and treated unequally in textbooks compared to males.

\section{The Language of the Body}

A positive step toward achieving gender equality is to portray males in unorthodox roles and body language, such as fear or worry, as evidenced by three textbook findings. However, no significant changes in the way women are depicted in textbooks can be observed, highlighting the necessity to reassess how women are represented in textbooks.

\section{Apparel}

Men are represented in various clothing, from casual to dressy, and mountaineering and diving equipment. On the other hand, women are restricted to traditional and everyday clothes, with only one instance of business wear. This is because most stories feature men in various character roles, whereas women are depicted in more conventional ones.

\section{Occupational Positions}

Men occupy more high-status careers than females, including Prime Minister, Soldier, Doctor, and Knight. Neutral characters are also assigned a variety of jobs, extending from high to low status. Nonetheless, female characters' vocational duties are more conventional. They are primarily limited to nurturing and caring occupations such as teachers, governesses, and so on, with no instance of male and female characters being equally represented in this section.

\section{Roles of Gender}

In addition to some instances when men and women are unconventionally represented, as the father sees the baking and buying of vegetables, the rest depicts them in their stereotypical social roles and duties. Women in the textbook take care of homes, feed children, care or warn, cook, and even negatively like witches, charmers, and objects of desire. 


\section{Hobbies and Features}

Most of the women in textbooks exhibit maternal attributes such as care, love, caring, nervousness, anxiety, gentleness, etc. Men show various features such as wrath, curiosity, ego, farsightedness, understanding, wisdom, compassion, spirituality, etc. In addition to positive traits, they possess negative characteristics, such as anger, revenge, roughness, manipulation, etc. The role of men weeping or fearing is stereotyped mainly with a few exceptions to sex.

\section{CONCLUSION}

The findings and discussion of this study have a variety of practical implications. As a result of the previous findings, it is clear that the textbook analyzed in this study contains gender stereotypes and unequal representation of both genders. The following are some of the implications for teaching and learning.

1. Textbooks indicated teaching students about social standards and values, showing acceptable and appropriate gender roles.

2. To avoid such issues, teachers must be aware of the information and ideas contained in the textbooks. Gender-neutral materials are one answer, but pupils may miss out on classic or literary works.

3. Another method is to avoid, prevent, and emulate the characters. A teacher should contrast the literary world from the real world and tell pupils about the timing of stories to illustrate why the different characters played their roles.

4. Comparing the roles and responsibilities of both genders in textbooks and real-life settings can stimulate critical thinking and challenge stereotyped conceptions and text portrayals.

5. Group discussions allow for another opportunity to restructure the text by assuring equitable representation of all genders.

The problem of gender representation in textbooks can be used to educate young learners. It must be addressed immediately, as these textbooks serve as a tool for change by propagating social norms and ideas about gender roles and responsibilities.

\section{REFERENCES}

Ariyanto, S. (2018). A portrait of gender bias in the prescribed Indonesian ELT textbook for junior high school students. Sexuality \& Culture, 22, 1054-1076. https://doi.org/10.1007/s12119-018-9512-8.

Cho, Y. \& Park, Y. (2014).Textbook as a contradictory melting pot: an analysis of multicultural content in Korean textbooks. Asia Pacific Journal of Education, http://dx.doi.org/10.1080/02188791.2014.924388, 1-20.

Dahmardeh, M., \& Kim, S.-D. (2020). Gender representation in Iranian English language coursebooks: Is sexism still alive? English Today, 36(1), 12-22. https://doi.org/10.1017/S0266078419000117. 
Damayanti, I. L. (2014). Gender construction in visual images in textbooks for primary school students. Indonesian Journal of Applied Linguistics, 3(2), 100- 116. https://doi.org/10.17509/ijal.v3i2.272.

Gebregeorgis, M. Y. (2016). Gender construction through textbooks: The case of an Ethiopian primary school English textbook. Africa Education Review, 13(3- 4), 119-140. https://doi.org/10.1080/18146 627.2016.1224579.

Keplinger, A., Kowal, J., Frątczak, E., Ławecka, K., Stokłosa, P. 2014a. "Job satisfaction and ethical behaviors premises of IT users insight from Poland, "Information Systems : Education, Applications, Research. Vol.193 (2014), pp. 49-64.

Lee, J. F. K. (2014). Gender representation in Hong Kong primary school ELT textbooks-A comparative study. Gender and Education, 26(4), 356-376. https://doi.org/10.1080/09540253.2014.916400

Lee, J. F. K. (2018). Gender representation in Japanese EFL textbooks-A corpus study. Gender and Education, 30(3), 379-395. https://doi.org/10.1080/09540253.2016.1214690.

Lee, J. F. K. (2019). In the pursuit of a gender-equal society: Do Japanese EFL textbooks play a role? Journal of Gender Studies, 28(2), 204-217. https://doi.org/10.1080/09589236.2018.1423956

Lee, J. F. K., \& Mahmoudi-Gahrouei, V. (2020). Gender representation in instructional materials: A study of Iranian English language textbooks and teachers' voices. Sexuality and Culture, 24, 1107-1127. https://doi.org/10.1007/s12119-020-09747.

Mengistie, S. M., \& Worku, M. Y. (2021). Gender Representation in Educational Materials: A Focus on Ethiopian English Textbooks. In W. L. Filho, A. M. Azul, L. Brandli, A. L. Salvia, \& T. Wall (Eds.), Gender Equality, Encyclopedia of the UN Sustainable Development Goals (pp. 599611). Cham: Springer.

Saputra, F. D. (2019). Gender representation in EFL textbooks. Edukasi, 6(1), 247259.

Sarvarzade, S., \& Wotipka, C. M. (2017). The rise, removal, and return of women: Gender representations in primary-level textbooks in Afghanistan, 19802010. Comparative Education, 53(4), 578- 599. https://doi.org/10.1080/03050068.2017.1348021.

Setyono, B. (2018). The portrayal of women in nationally-endorsed English as a foreign language (EFL) textbooks for senior high school students in Indonesia. Sexuality and Culture, 22, 1077-1093. https://doi.org/10.1007/s12119-018- 9526-2

UNESCO (2009), Promoting Gender Equality through Textbooks: A Methodological Guide. UNESCO France .

UNESCO (2011). Priority Gender Equality Guidelines. Retrieved from http://www.unesco.org/new/fileadmin/MULTIMEDIA/HQ/BSP/GENDER /G E\%20Gu idelines\%20December\%202_FINAL.pdf

World Health Organisation. Adolescent Development. http://www.who.int/maternal_child_adolescent/topics/adolescence/develop me nt/en. 
Widodo, H. P. (2015). The development of vocational English materials from a social semiotic perspective: Participatory action research (Doctoral Dissertation). Australia: University of Adelaide.

Widodo, H. P. (2016). Language policy in practice: Reframing the English language curriculum in the Indonesian secondary education sector. In R. Kirkpatrick (Ed.), English language education policy in Asia. (pp. 127-151). Cham: Springer.

Widodo, H. P. (2018). A critical micro-semiotic analysis of values depicted in the Indonesian Ministry of National Education-endorsed secondary school English textbook. In H. P. Widodo, M. R. Perfecto, L. V. Canh, \& A. Buripakdi (Eds.), Situating moral and cultural values in ELT materials: The Southeast Asian context. (pp. 131-152). Cham: Springer

Widodo, H. P., \& Elyas, T. (2020). Introduction to gender in language education. Sexuality \& Culture, 24, 1019-1027. https://doi.org/10.1007/s12119-02009753-1

Wodak, R. (2001). What CDA is about: A summary of its history, important concepts and its development. In R. Wodak \& M. Meyer (Eds.), Methods of critical discourse analysis (pp. 1-13). London: Sage.

Yang, C. C. R. (2016). Are males and females still portrayed stereotypically? Visual analyses of gender in two Hong Kong primary English Language textbook series. Gender and Education, 28, 674-692. https://doi.org/10.1080/09540253.2015.1103839. 